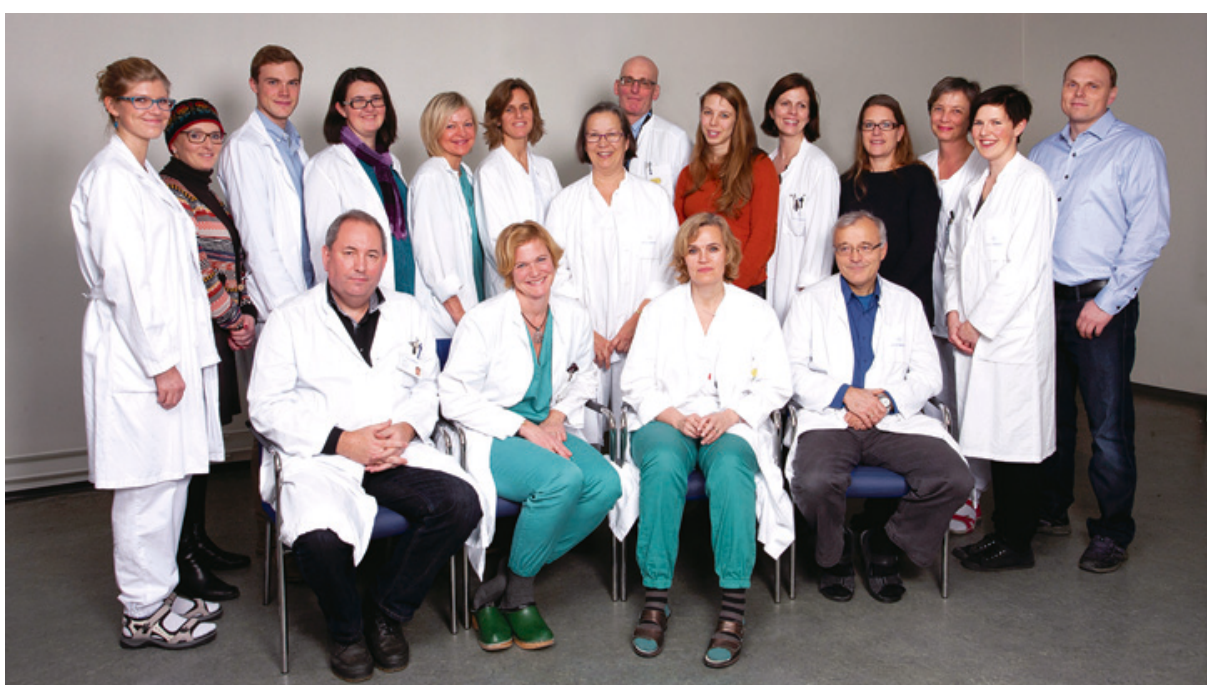

Forskergruppen i Bergen. Helga B. Salvesen, nummer to fra venstre på første rekke, har ledet studien sammen med Matthew Meyerson. Foto: Anne Sidsel Herdlevær, Universitetet i Bergen

\title{
Nye genfunn ved livmorhalskreft
}

En studie ledet av norske og amerikanske forskere har kartlagt

genforandringer ved livmorhalskreft i detalj.

Livmorhalskreft er den tredje vanligste kreftformen blant kvinner og er årsaken til rundt $10 \%$ av alle kreftdødsfall. Livmorhalskreft er sterkt assosiert med seksuelt overført humant papillomvirus (HPV-virus). Livmorhalskreft er hyppigst i utviklingsland, der forebygging ved masseundersøkelser og vaksinasjon sjelden gjøres.

Leger og forskere fra Bergen, Boston og Mexico City har for første gang gjort en omfattende kartlegging av genforandringene ved livmorhalskreft. Studien er nylig publisert i Nature (1). Forskerne studerte alle genene i 115 kreftsvulster fra livmorhalsen og fant 13 hyppige mutasjoner. Åtte av disse har ikke vært påvist ved livmorhalskreft tidligere, og to mutasjoner har aldri vært funnet i kreftsvulster før. Ett av de viktigste funnene var såkalte somatiske punktmutasjoner i genet $E R B B 2$. Mutasjoner i dette genet kan man også finne ved brystkreft, og målrettet behandling mot denne mutasjonen brukes i brystkreftbehandling.

Forskerne fant også ut mer om hvorfor HPV-infeksjon i livmorhalsen kan føre til utvikling av kreft. Når humant papillomvirus integreres i DNA i livmorhalsens celler, kan gener som fører til at kreftsvulster vokser bli aktivert.

- Denne studien støtter antakelsen om at vaksinasjon mot humant papillomvirus er viktig for å forebygge livmorhalskreft, sier overlege og professor Helga B. Salvesen ved Haukeland universitetssykehus, som sammen med professor Matthew Meyerson ved Dana-Farber Cancer Institute og Broad Institute of Harvard and Massachusetts
Institute of Technology i Boston har ledet studien. - Funnene av nye genmutasjoner kan gjøre det mulig å utvikle nye medikamenter.

- Behovet for bedre og mer effektiv medisinsk behandling ved livmorhalskreft er stort, særlig mot spredning. Håpet er at en kombinasjon av vaksinasjon og mer målrettet terapi vil gjøre oss bedre i stand til å forebygge og behandle livmorhalskreft, sier Salvesen.

\section{Forskergruppen}

Studien bygger på et internasjonalt samarbeid som har pågått siden 2004. Forskergruppen ved Haukeland universitetssykehus og Universitetet i Bergen bidro til å etablere samlingen av svulstvev fra pasienter behandlet for gynekologisk kreft. Bjørn Bertelsen, overlege i patologi, klassifiserte kreftsvulstene. Olav Vintermyr, professor i patologi, karakteriserte de ulike HPVtypene i svulstene.

Forskergruppen i Bergen består også av mange andre fagpersoner, hvorav flere er medforfattere av artikkelen. Gruppen er støttet økonomisk av bl.a. Helse Vest, Norges forskningsråd, Universitetet i Bergen, Kreftforeningen og Harald Andersens legat.

\section{Kari Tveito}

Tidsskriftet

\section{Litteratur}

1. Ojesina Al, Lichtenstein L, Freeman SS et al. Landscape of genomic alterations in cervical carcinomas. Nature 2013; e-publisert 25.12.2013.
Ordforklaringer:

HPV: Humant papillomvirus

ERBB2: Forkortelse for v-erb-b2 avian erythroblastic leukemia viral oncogene homolog 2 , også kjent som HER-2. Genmutasjon som disponerer for brystkreft og livmorhalskreft.

HPV-integrering: Hvordan humant papillomvirus er bygd inn i det menneskelige arvestoffet DNA. 